\title{
Acetylsalicylic acid potentiates passive systemic anaphylaxis in mice
}

\author{
Maria Nassiri', Magda Babina, Margitta Worm \\ From Food Allergy and Anaphylaxis Meeting 2011 \\ Venice, Italy. 17-19 February 2011
}

Acetylsalicylic acid (ASA) is a nonsteroidal anti-inflammatory drug that can cause mast cell dependent diseases in sensitive individuals. ASA induced asthma is believed to be related to an overproduction of cysteinyl leukotriene C4. (LTC4) secondary to cyclooxygenase inhibition. It remains to be elucidated whether and by which mechanisms ASA may also influence systemic anaphylactic reactions.

In order to clarify if ASA modulates passive systemic anaphylaxis (PSA), Balb/c mice were pre-treated with ASA, sensitized with anti-TNP-BSA intravenously followed by intravenous challenge with TNP-BSA. The temperature profile was assessed for $70 \mathrm{~min}$. Levels of mast cell mediators in the sera (histamine, serotonin, LTC4) were determined by ELISA. Additionally murine bone marrow-derived cultured and peritoneal mast cells were incubated in vitro with ASA, loaded with IgE, stimulated with anti-IgE and histamine release was assessed.

ASA aggravated the symptoms of PSA; the maximum temperature drop for ASA pre-treated mice was $5.1 \pm$ 0.4 versus $3.7 \pm 0.5$ in the control $(p=0.004)$. In line with exacerbated hypothermia, elevated amounts of mast cell mediators were found in mouse sera. LTC4 was enhanced and most interestingly, increases in the preformed mediators histamine and serotonin were likewise detected. Contrary to these findings the histamine release of mast cells incubated with ASA in vitro was reduced.

Together, ASA potentiates PSA probably by enhancing the degranulation of mast cells in vivo, thereby increasing the availability of anaphylactic mediators. Since ASA suppresses mast cell activation in vitro, the environment surrounding the mast cells dictate most likely changes in the releasability of these effector cells upon ASA

Allergie Centrum-Charite, Klinik für Dermatologie und Allergologie, Campus Charité Mitte, Charité- Universitätsmedizin, Berlin, Germany treatment. Our findings emphasize the importance of in vivo models to study anaphylaxis as only in vivo experiments can unravel the complex interplay of different cells and tissue factors.

Published: 12 August 2011

doi:10.1186/2045-7022-1-S1-025

Cite this article as: Nassiri et al.: Acetylsalicylic acid potentiates passive systemic anaphylaxis in mice. Clinical and Translational Allergy 20111 (Suppl 1):O25.
Submit your next manuscript to BioMed Central and take full advantage of:

- Convenient online submission

- Thorough peer review

- No space constraints or color figure charges

- Immediate publication on acceptance

- Inclusion in PubMed, CAS, Scopus and Google Scholar

- Research which is freely available for redistribution
() Bïomed Central

\section{Biomed Central}

